\title{
SOFT SKILLS TRAINING: COLLEGE TEACHING THAT MATTERS AND LEARNING THAT LASTS FOR EMERGING PROFESSIONALS
}

\author{
Ioseb Gabelaia \\ Ph.D-c, Transport and Telecommunications Institute, LATVIA, iosebgabelaia@gmail.com
}

\begin{abstract}
Today, Higher educational institutions are challenged more than ever. Employers demand skilled graduates who impact workplaces. They need critical and creative thinkers, problem-solvers, decision-makers, personalities with people management, and so on. Shortly, they need soft skills trained people. Today, Learners are smarter. They tend to understand market expectations and that increases the demand for highquality education.
\end{abstract}

Soft skills training programs have been becoming a major trend in higher education. Nowadays, universities must work carefully with students. They must encourage and develop various skills in the areas of their expertise. They must understand that soft skills make the difference between adequate and ideal candidates. Universities must incorporate applied sciences into the learning and curriculum. It enables institutions to nurture future career skills. It is an opportunity to build three-way collaborations between universities, employers, and students.

Higher educational institutions must recognize that college education is facilitation. Today, students need mentors and coaches, people who can put them on the right path. Students can do self-learning with enormous data available, however, instructors must expedite the learning.

New graduates are emerging future professionals. Institutions must arm them will the essential skills to survive in competitive job markets. The employers have no limits on recruitment criteria or the knowledge they look for. Perhaps, successful college graduates impact the marketing visibility, image, and brand of the institutions. Hence, to differentiate from competitors, universities must produce valuable job candidates.

Graduates are potential workplace leaders. In college, they have four years to develop skills and shape their abilities. Communication skills, leadership skills, adaptability, workplace ethic, teamwork, El (Emotional Intelligence), and so on are the primary armory of the students. To a certain extent, soft skills training programs within the educational curriculum enhance those skills. Soft skills training programs within the graduates build a sense of confidence, accountability, and responsibility.

Every job requires some type of interaction, consequently, soft skills are important for many employers. Though, how colleges can deal with online or distance learning? The distance learning trend takes away valuable interaction time. The study believes that it is vital for universities to create collaborations with moving variables. Competitive institutions will find the happy learning medium.

The goal of the study is to analyze the relevance of college teaching that matters and learning that lasts. The study elaborates on the importance of soft skills training trend withing college education, and how it impacts learners. The study selects and analysis the top seven soft skills that are believed are critical for the student career path. Nevertheless, the study discusses the challenges of soft skills training in college education.

The objective of the study is to see if soft skills training programs create a competitive advantage for universities. Also, for learners at their potential workplaces. The study intends to conduct and prepare an appropriate analysis. The study seeks to present valuable suggestions for educational institutions, as well as for students. The study aspires to remind how important it is to have highly educated and skilled graduates. 
The study uses a mixed research methodology. At first, the Study will interview several educational specialists, as well as graduates. The interview asks four main questions about the relevance of soft skills training and reason for trending. Second, to support interview analyses, and theoretical data, study employees an online survey. The study asks comparative research questions to find thought differences. The online survey asks scale, drop down, and multiple-choice type questions to obtain data about soft skills training. The Likert scale will be utilized to obtain a holistic view of respondents on selected top seven soft skills.

The outcome of the study either will accept or reject the relevance of Soft Skills Training: College teaching that matters and learning that lasts for the future of student careers. Analyzed data will assist to draw recommendations for higher educational institutions. Additionally, it will add suggestions for college students on their roles in facilitated education. Finally, the study believes that besides recommendations the research will raise the applicability of soft-skills training into college education.

Keywords: Soft skills, training, employment, college teaching, institutions

\section{INTRODUCTION}

In the modern world, every job requires some type of interaction and engagement, whether traditional or digital. Consequently, the knowledge and understanding of soft skills are crucial for many employers. Digital channels take away the valuable time of interaction and communication. Though, the study believes that it is vital for universities to create collaborations with moving variables. Competitive institutions will find the happy learning medium. Eventually, the goal must be to create a sustainable learning condition.

Today, Higher educational institutions are challenged more than ever. According to (Tulgan, 2015), todays's newest new young workforce has so much to offer - new technical skills, new ideas, new perspectives, new energy. Yet, too many of them are held back - and driving the grownips crazy - because of their weak soft skills. Employers demand skilled graduates who impact workplaces. They need critical and creative thinkers, problem-solvers, decision-makers, personalities with people management, and so on. Shortly, they need soft skills trained people.

Employers understand that potential employees might have a great professional skill in the field of the study, or/and career. (Kamin, 2013) states that employers view soft skills as even more important than the three R's (reading, writing, and arithmetic). However, they want more. They want to know the personality-driven aspects of potential employees. Employing the right talents is a though-through process. Employers tend to oversee professional experiences and qualifications for the right soft skill's suited candidates.

Today, Learners are smarter. They tend to understand modern employment market expectations. Hence, they demand high-quality education from universities. Higher educational institutions must recognize that college education is facilitation. Today, lecturing is more then what it is. Learners highly regard trustworthiness and approachability. Students need mentors and coaches, people who can put them on the right path. Students can do self-learning with enormous data available, however, instructors must expedite the learning. Additionally, university mentors and coaches must align students' soft skills within the chosen career path.

Soft skills training programs have been becoming a major trend in higher education. Nowadays, universities must work carefully with students. They must encourage and develop various skills in the areas of their expertise. They must understand that soft skills make the difference between adequate and ideal candidates. Soft skilled employees are needed not only to build and maintain relationships with external clients but also to effectively interact with internal teams. Businesses invest resources to create teams where employees strive together while achieving common objectives.

Universities must incorporate applied sciences into the learning curriculum. It enables institutions to nurture future career skills. It is an opportunity to build three-way collaborations between universities, employers, and students. New graduates are emerging future professionals. Institutions must arm them will the essential skills to survive in competitive job markets. The employers have no limits on recruitment criteria or the knowledge they look for. Moreover, graduates are potential workplace leaders. In college, they have four years to develop skills and shape their abilities. Communication skills, leadership skills, adaptability, workplace ethic, teamwork, El (Emotional Intelligence), and so on are the primary armory of the students. To a certain extent, soft skills training programs within the educational curriculum enhance those skills. Soft 
skills training programs within the graduates build a sense of confidence, accountability, and responsibility.

Soft skills must be constantly developed and improved. Learners must analyze the strength and weaknesses of soft skills. (Beard, Schweiger, \& Surendran, 2019) asses integration of soft skills through university,college and programmatic efforts. Soft skills are learned over time. A college graduate will not have excellent soft skills without practical experience at college. Today, many individuals go back to college, or take online courses, or participate in training programs. It is an indication, how important is it to develop various soft skills to progress in a career, build better relations, or so on. Lastly, to improve soft skills is a challenging process.

Successful college graduates impact marketing visibility, consequently, institutions' brand image, awareness, and recognition. Hence, to differentiate from competitors, universities must produce valuable job candidates. Directly or indirectly, it is a university's responsibility to assist and provide specialized training programs within the university. Those programs must enhance the soft skills of undergraduate or graduate students. A sustainable future requires sustainable education. Therefore, college graduates must in constant soft skills development process.

\subsection{Top Seven Soft Skills}

College teaching that matters and learning that lasts is a cornerstone of the educational process. According to (Nilson, 2014) people may be born to learn, but they are not born knowing the best strategies to learn all the declarative, procedural, and conditional knowledge that they encounter in life. From a business perspective, institutions must promote commitment to the quality of education. They must engage prospective students, parents, stakeholders, and so on. From an education perspective, institutions must facilitate teaching that has a valuable impact on the student and learning which will be utilized in the longterm professional careers. (Goldberg \& Rosenfeld, 2014) describe that People-Centric Skills aim to improve all aspects of personal interactions, relatinship development, and communications. These skills are as essensial as are the technical skills.

The trend of soft skills training enables institutions to battle in a competitive environment. (Lippman, Ryberg, Carney, \& Moore, 2015) explains that soft skills are skills, competences, behaviors, attitudes, and personal qualities that enable yout to navigate their environment and achive their goals. Globally, learners have many options to choose from. So, institutions must invest more in allocating this trend and contribute to mentoring and coaching learners.

The study analyzed various literature on soft skills and selected the top seven skills. To illustrate, (Goldberg \& Rosenfeld, 2014) claim that the People-Centric Skills include, but are not limited to: communications in all mediums, conflict resolution, active listneing, leadership, mentoring and coaching, effective teaming and team dynamics, assessing corporate culture, and so on. The study believes that selected soft skills present extensive value to the learners. Those skills are the difference makers in any type of business. Furthermore, those skills must enable universities, learners, and businesses to collaborate and create coordinated soft skills training programs.

Table 1. Top Seven Soft Skills

Top Seven Soft Skills

\begin{tabular}{|l|l|}
\hline \multicolumn{2}{|l|}{ Top Seven Soft Skills } \\
\hline Communication & $\begin{array}{l}\text { Employers want excellent communicators. Any job requires communication } \\
\text { on different levels. Communication builds relationships. Communication } \\
\text { keeps the retention of customers, and so on. Listening, hearing, verbal and } \\
\text { nonverbal aspects are critical in the communications world. Communication is } \\
\text { the cornerstone of soft skills. }\end{array}$ \\
\hline $\begin{array}{l}\text { Conflict Resolution } \\
\text { and Negotiation }\end{array}$ & $\begin{array}{l}\text { The employer considers candidates who excellent negotiators. Today, the } \\
\text { possible conflicts in the workplace, or within the competition are high. } \\
\text { However, conflicts must not last long, as it damages both sides. Having soft } \\
\text { skills in conflict management and negation is a must. }\end{array}$ \\
\hline Adaptability & $\begin{array}{l}\text { Employers consider a candidate who can acclimate to the constantly } \\
\text { changing workplace. In a competitive market, circumstances regularly } \\
\text { change. The ability to concentrate and keep cool is the must. }\end{array}$ \\
\hline
\end{tabular}




\begin{tabular}{|l|l|}
\hline Creativity & $\begin{array}{l}\text { Employers consider candidates who are creative, meaning individuals who } \\
\text { bring uniqueness to the workplace. Uniqueness encourages competition, } \\
\text { thinking, collaboration, new idea generations, and so on. }\end{array}$ \\
\hline Problem-Solving & $\begin{array}{l}\text { Employers consider candidates who have strong problem-solving skills. } \\
\text { Today's working environment is chaotic and needs individuals with cool head- } \\
\text { on, with critical and creative decision-making skills. }\end{array}$ \\
\hline Work Ethic & $\begin{array}{l}\text { Employers consider candidates who have self-motivation, leadership, and } \\
\text { flexibility soft skills. Those skills enhance workplace effectiveness and } \\
\text { efficiency. }\end{array}$ \\
\hline Time Management & $\begin{array}{l}\text { Employers consider candidates with a clear mind and thinking, a decisive } \\
\text { attitude, the ability to work under pressure, and the ability to manage work } \\
\text { stress. In the fast-paced work environment, meeting certain deadlines are the } \\
\text { must, and/or deal breakers. }\end{array}$ \\
\hline
\end{tabular}

The chosen top seven skills develop discipline, motivation, accountability, and teamwork within learners. It allows learners to access and analyze information, and anticipate possible consequences (Bastin \& Alagra, 2018). Finally, all the top seven skills, and not only, demand commitment from learners.

\subsection{The Challenges of Soft Skills Training in College Education}

The study has chosen facilitating learning versus teaching as a top challenge. The focus on this challenge is based on what employers require. Today, many institutions apply applied science to learning. Yet, many course leaders do not have the practical experience to teach real-life examples. The study believes that learners learn from real examples, therefore it facilitates understanding of theories.

Institutions cannot just employ soft skills training into the curriculum without having solid programs, where learners can learn. Having the program is one part. The need for a qualified trainer is another and significant part. Many institutions have lifelong learning centers, however, not many utilize them as it must be.

The role of a teacher in college is facilitation, to help learners how to expose and understand information and understand how to learn it. (Hornickel, 2013) states that there is an aspect of the mind - a very powerful aspect- that has its own agenda and, when active, usually produces nagative thoughts,feelings and actions. Therefore, learners need tremendous support to understand available vast data. Facilitation enables that support. It equips them with the necessary tools.

\section{RESEARCH METHODOLOGY AND DESIGN}

The goal of the study was to analyze the relevance of college teaching that matters and learning that lasts. The study used a mixed research methodology. At first, the Study interviewed seven educational specialists, and five college graduates. The interview asked four main questions about the relevance of soft skills training and reason for trending. Second, to support interview analyses, and theoretical data, the study employed an online survey.

The study asked comparative research questions to find thought differences. The online survey asked scale, drop down, and multiple-choice type questions to obtain data about soft skills training. The Likert scale was utilized to obtain a holistic view of respondents on selected top seven soft skills.

\section{RESEARCH OBJECTIVES}

The study had following objectives:

1. To analyze the relevance of college teaching that matters and learning that lasts.

2. To discuss the importance of soft skills training trend withing college education, and how it impacts learners.

3. To selects and analysis, the top seven soft skills that are believed are critical for the student career path.

4. To discuss the top challenge of soft skills training in college education. 
5. To see if soft skills training programs create a competitive advantage for universities.

\section{RESEARCH FINDINGS}

The data collection was conducted between December 1st, 2019 - April 17th, 2020. The target population of the study was college students and education specialists. The data was collected through interviews. Seven education specialists and five college graduates answered four interview questions. All participants willingly answered and provided feedback. The four questions were: First, How important is it for learners to have strong soft skills? Second, Do you think institutions must incorporate soft skills training into the academic curriculum? Third, Do you agree with the statement " graduates do not know how to think, learn, and communicate without checking a device?" And the last, the main question, How do you understand the statement, " college teaching that matters and learning that lasts for emerging professionals"?

In the same time range, the online survey was conducted. The population size for the sample was 100 with an anticipated $20 \%$ response rate. College students and educational specialists were asked to provide their feedback. 74 participants responded to the inquiry.

The study asked respondents to rank the importance of soft skills. 1-being lowest, 5-being highest. From 74 respondents, $11(14.9 \%)$ ranked it "1", $13(17.6 \%)$ ranked "2", $13(17.6 \%)$ ranked "3", $24(32.4 \%)$ ranked "4", and $13(17.6 \%)$ ranked " 5 ". Furthermore, respondents were asked should universities implement soft skills training into a college education? Figure 1 Illustrates the following. From 74 participants, $3(4.1 \%)$ selected "strongly disagree", 17 (23\%) "Disagree", 22 (29.7\%) "Neutral", 19 (25.7\%) "Agree" and 13 (17.6\%) selected "Strongly agree".

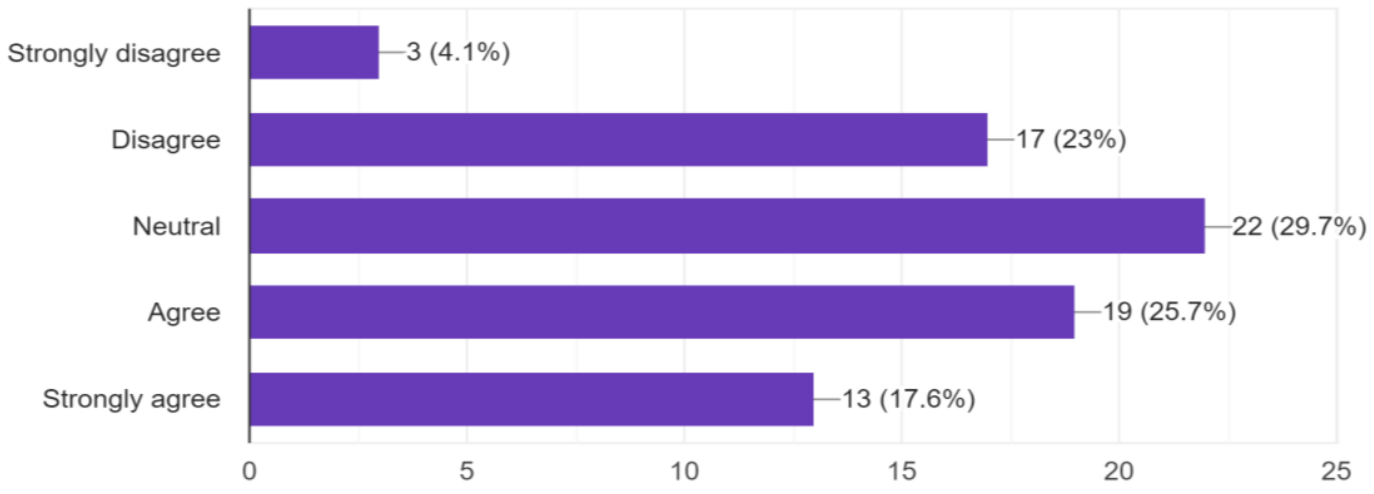

Fig. 1. Implementing Soft Skills Training into a College Education. The majority of respondents have a neutral opinion, however, still a huge sum agrees on implementing it.

The study asked respondents to select one, how was the delivery of the course work in the classroom? From 74 respondents, $7(9.5 \%)$ said "Theoretical", $3(4.1 \%)$ "Practical", $26(35.1 \%)$ "more theory to the practical ratio", $22(29.9 \%)$ "more practical to theory ratio" and $16(21.6 \%)$ said, "practical significantly overtakes theory". The study continued with the next questions. Rank, how do you react when you hear that college graduates are unprofessional with terrible people skills? 1-being lowest, 5-being highest. Figure 2 illustrates the following. From 74 respondents $20(27 \%)$ ranked "1", 36 (48.6\%) ranked "2", $16(21.6 \%)$ ranked "3", $2(2.7 \%)$ ranked " 4 " and $0(0 \%)$ ranked " 5 ".

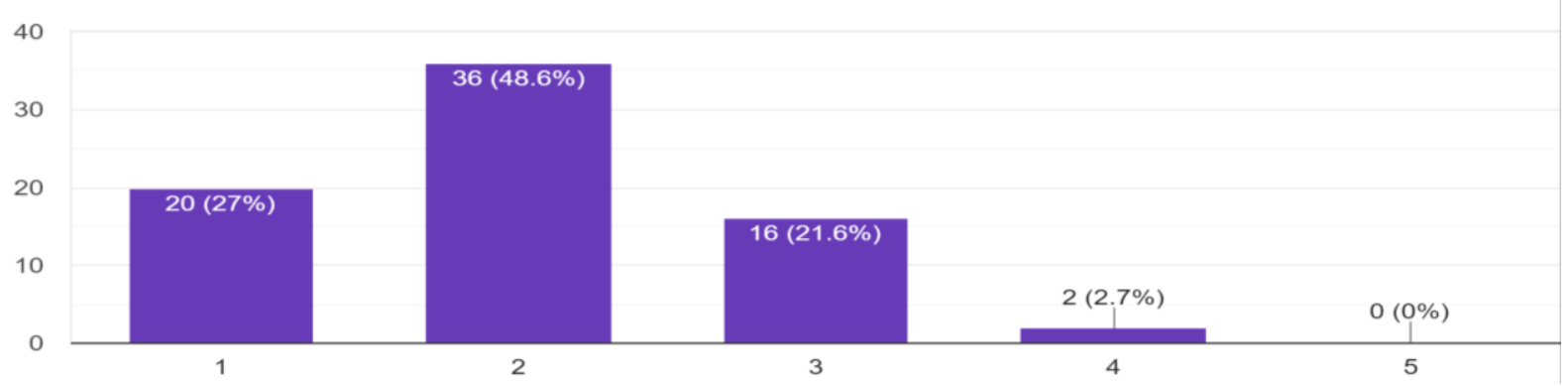

Fig.2. Reaction on Statement " Graduates are Unprofessional with Terrible People Skills". Majority of respondents ranked " 2 " and " 1 ", indicating that they are positive on what is said. 
The study asked respondents to select the top two soft skills they possessed from selected top 7 soft skills. Figure 3 illustrates the following. Communications 24 (32.4\%), Conflict resolution and negotiation 20 (27\%), adaptability $16(21.6 \%)$, creativity $25(33.8 \%)$, Problem solving 24 (32.4\%), Work ethic $23(31.1 \%)$ and Time management $16(21.6 \%)$.

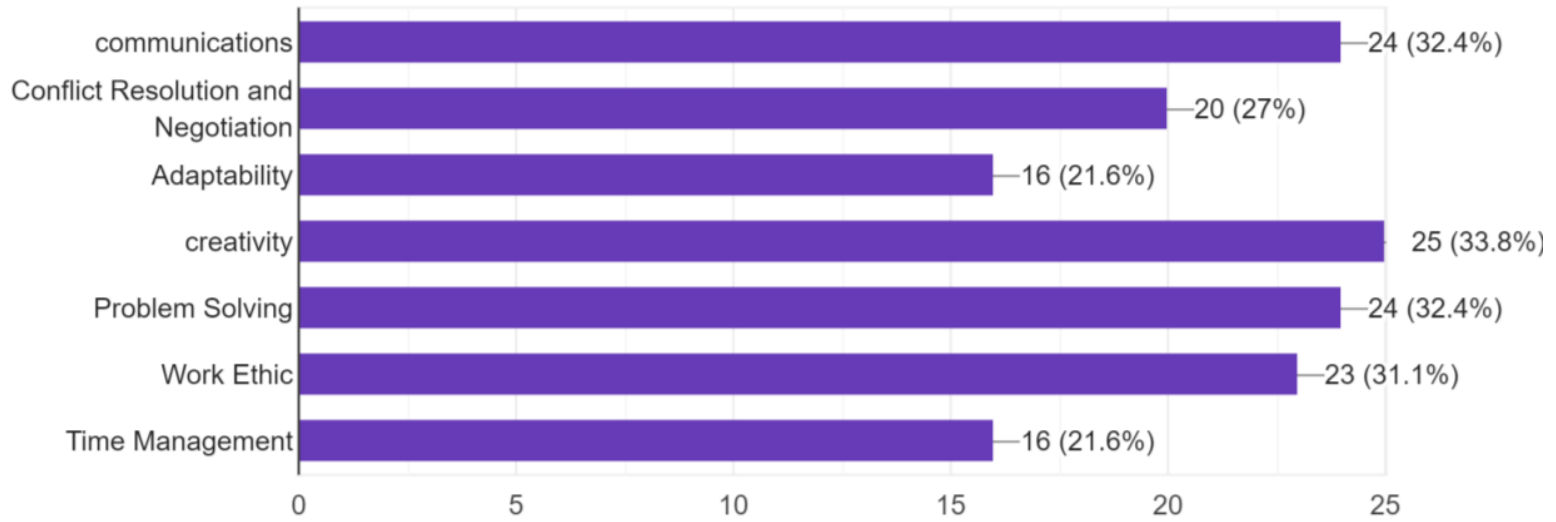

Fig.3. Selection of Soft Skills possesed. Creativity, Problem Solving and Communication skills are top soft skills possed by the respondents. Time management and adaptability are least possed skills.

The study asked the last question to rank selected seven soft skills. 1-being lowest, 5-being highest. Table 2.1 illustrates the following. Highest ranking seven soft skills received was " 3 ", followed by "4", next " 2 ", last but not least " 5 " and last was " 1 ".

Table 2. Ranking of Sevel Soft Skills

\begin{tabular}{|l|l|l|l|l|l|l|l|}
\hline $\mathrm{N}$ & Communication & $\begin{array}{l}\text { Conflict Resolution } \\
\text { and Negotiation }\end{array}$ & Adaptability & Creativity & $\begin{array}{l}\text { Problem } \\
\text { Solving }\end{array}$ & $\begin{array}{l}\text { Work } \\
\text { Ethic }\end{array}$ & $\begin{array}{l}\text { Time } \\
\text { management }\end{array}$ \\
\hline 1 & 3 & 1 & 6 & 2 & 1 & 4 & 3 \\
\hline 2 & 11 & 19 & 17 & 17 & 17 & 17 & 18 \\
\hline 3 & $\mathbf{2 1}$ & $\mathbf{3 5}$ & 19 & $\mathbf{2 3}$ & $\mathbf{2 8}$ & $\mathbf{2 6}$ & $\mathbf{2 4}$ \\
\hline 4 & $\mathbf{2 6}$ & 12 & $\mathbf{2 3}$ & $\mathbf{2 4}$ & 15 & 18 & 16 \\
\hline 5 & 13 & 7 & 9 & 8 & 13 & 9 & 13 \\
\hline
\end{tabular}

\section{DISCUSSION}

Today, according to (Tulgan, 2015) managers constantly remind that college graduates are not prepared to face the real world. Some of the statements shared are " they don't take personal responsibility or hold themselves accountable", "they need attitude adjustment", "their people skills are terrible", "their work habits, and self-awareness is terrible", and so on. It is an indication, how important is it to prepare graduates to the workforce, and equip them with strong soft skills.

(Kamin, 2013) indicates that when you meet someone for the first time, you form an immediate impression. The impression has nothing to do with titles, whether the man or woman is the director of the counselor. The impression you have is how the person chooses to communicate with you. In today's competitive environment many college students, and not only, do not understand the value of soft skills. However, the trend is rising.

College students understand that they must possess some type of soft skills, or should have some type of training. College graduate does not have much experience. They might have had some leadership positions, or job opportunities while at college, however, nothing compares to the real-time experience. The study shows that from 74 respondents, $11(14.9 \%)$ ranked it "1", 13 (17.6\%) ranked "2", 13 (17.6\%) ranked "3", 24 $(32.4 \%)$ ranked "4", and $13(17.6 \%)$ ranked "5" the importance of soft skills. From numbers, the study understands that respondents are not sure about the role of soft skills. Figure 1.1 confirmes this notion, where respondents are again divided on if soft skills training is it should be part of the college curriculum. 
During the interviews, respondent 4 was very emotional about the role of soft skills into the academic curriculum. Respondent 4 believed that for students to be successful and to have a long term future, they must be taught how to become champions of themselves. He underlined "champion of themselves" several times. In contrast, respond 2 on the same question was not concerned. Respondent 2 believed that soft skills do not make much difference. She said as long as the job is done, it is done and nothing else matters. The study has two different views that indicate the division of the thoughts on soft skills.

(Tulgan, 2015) continues that there is a growing gap between the expectations of employers and the reality of how today's new young talent is showing up in the workplace. The study asked respondents to select one, how was the delivery of the course work in the classroom? From 74 respondents, 7 (9.5\%) said "Theoretical", 3 (4.1\%) "Practical", 26 (35.1\%) "more theory to the practical ratio", 22 (29.9\%) "more practical to theory ratio" and $16(21.6 \%)$ said, "practical significantly overtakes theory". The results are not troubling, however, the study believes that it is troubling. There must be more practical work included in classroom education. The study believes that if soft skills training are employed into learning, the learners will benefit more. They will be better equipped with soft skills. Therefore the growing gap between expectations and the reality will slow. It will benefit both sides. However, the study believes that there are long ways until the growing gap can be reduced.

In the study respondent ranked the soft skills between "2" and " 4 ". The study understands that respondents feel the need for soft skills. The study believes that question \#5 challenged respondents as they had to react to what managers think of them. The question was asked on purpose before they had to select and rank soft skills. The majority of the respondents were college students, and that indicates why respondents reacted negatively to the statement "unprofessional with terrible people skills". The initiative was to trigger more awareness of soft skills.

On the last interview question, how do you understand the statement " college teaching that matters and learning that lasts for emerging professionals"? respondents opened up. Respondent 3 reacted saying " teaching must facilitate learning that students will take forever," Respondent 6 said "learning in the classroom must be done by professionals who have worked or are still working in the private sector. That way learners will have more insights on soft skills and behaviors. Just proving information does not help. It is important to know is suggestions worked and/or work in real-time". Respondent 1 was critical of education. She said "I feel like I just opened eyes. I never thought of education from this perspective. I need to dedicate more time to learning, and ask for more information".

\section{CONCLUSION}

A healthy work environment does not only depends on hard skills. Soft skills are equally important. From the literature and practical analysis, the study believes businesses will continue investing in a talent search. The most demanding aspect will be soft skills. It is valuable to find and prepare talented individuals for leadership roles. The workplace is interpersonal space, and the need for an effective workforce is the must. The demand comes from businesses, and the institutions must supply efficient human capital.

The study met the research objective of analyzing the relevance of college teaching that matters and learning that lasts. The future is in hands of learning, whether traditional or digital. Today, learners represent consumer power. They dictate businesses on what to produce. Therefore, they have the power to dictate universities to provide quality education. The need for soft skills is a must, whether it is the traditional or digital environment. To be ahead of the competitions, universities must improvise and plan for long-term benefits compared to the short term.

The study, through theoretical analysis, studied top soft skills. The study expects to receive arguments about the selection. The study provided several soft skills that are believed to be essential for today's fast-changing workplace. Those soft skills must be embraced and learned by college students. The workplace is not a safe world. It is full of competition. If someone is not learning, or/and improving skills, there is always another who is waiting for his/her chance.

The study underlines facilitating learning versus teaching as the challenge. The respondents did provide some information, however, they still seemed lost in understanding what does facilitate learning means. It is not their fault. The study believes that businesses must be more critical, learners more enthusiastic that will demand from institutions to provide the right curriculum. The winning is not to create top CEO's, rather leaders with future vision equipped with the necessary knowledge.

Inserting soft skills training programs will benefit universities. The study believes that for institutions to differentiate themselves in the competitive market, they must do something different. Taking a risk does not 
mean failing, but the opposite. It creates a unique environment. Today, learners look for unique experiences, and institutions must use it. The time of want and need is gone. Learners want to experience it. Soft skills training programs in the curriculum will make graduates more effective and efficient. At the end of the day, satisfied students mean, satisfied businesses, and satisfied universities. It is a triple win.

Based on theoretical studies, interviews, and survey analysis the study concludes and provides the following recommendations. First, to enhance soft skills, the suggest partaking in self-reflection. Learning starts with understanding self. You must be honest with yourself. Genuinely discuss and analyze strengths and weaknesses. Ask for critique from the surroundings. Second, participate in various training, whether face-toface or online. Search for various programs. Select programs that self needs. In both situations, you can learn various soft skills. Those training will help to observe people around and learn how to read soft skills in others. And lastly, constantly be engaged. Moreover, constantly invest in personal development.

The research accepts the relevance of soft skills training: college teaching that matters and learning that lasts for the future of student careers is a trend that must continue. The study showcased the importance and relevance of soft skills training in college education. The study hopes to fill the knowledge gap and facilitate soft skills training into college education. Lastly, the study recognizes that the trend will challenge educators.

\section{REFERENCE LIST}

Bastin, J. V., \& Alagra, A. (2018). Soft Skills for Career Success: Soft Skills. New Delhi: Educreation Publishing.

Beard, D., Schweiger, D., \& Surendran, K. (2019). Integrating Soft Skills Assessment through University, College, and Programmatic Efforts at an AACSB Accredited Institution. Journal of Information Systems Education, 19(2). Retrieved from https://aisel.aisnet.org/jise/vol19/iss2/11

Goldberg, D. M., \& Rosenfeld, M. (2014). People-Centric Skills : Interpersonal and Communication Skills for Auditors and Business Professionals. Hoboken, New Jersey: John Wiley \& Sons, Incorporated.

Hornickel, J. (2013). Negotiating Success : Tips and Tools for Building Rapport and Dissolving Conflict While Still Getting What You Want. Hoboken, New Jersey : John Wiley \& Sons, Incorporated.

Kamin, M. (2013). Soft Skills Revolution : A Guide for Connecting with Compassion for Trainers, Teams, and Leaders. San Francisco: Center for Creative Leadership.

Lippman, L., Ryberg, R., Carney, R., \& Moore, K. (2015, June). Workforce connections: key 'soft skills' that foster youth workforce success: toward a consensus across fields. Retrieved from childtrends.org: https://www.childtrends.org/wp-content/uploads/2015/06/2015-24WFCSoftSkills1.pdf

Nilson, L. B. (2014). Teaching at Its Best : A Research-Based Resource for College Instructors. Hoboken, New Jersey : John Wiley \& Sons, Incorporated.

Tulgan, B. (2015). Bridging the Soft Skills Gap : How to Teach the Missing Basics to Todays Young Talent. Hoboken, New Jersey: John Wiley \& Sons, Incorporated. 